\title{
THE GREAT NEGLECT: THE FATE OF MENDEL'S CLASSIC PAPER BETWEEN 1865 AND 1900
}

\author{
by \\ E. POSNER and J. SKUTIL* \\ 'Truly epoch-making were his experiments in plant-hybridization'. \\ (anonymous writer, 1884). \\ 'Nevertheless the total neglect of such a discovery is not easy to \\ account for ...' \\ (W. Bateson, 1909, p. 333).
}

GREGOR MeNDel read his paper Versuche über Pflanzenhybriden (Experiments in Plant Hybridization) at two sessions of the Natural History Society of Brünn, now Brno, in February and March 1865. The two lectures were published in Volume IV of the Verhandlungen des Naturforschenden Vereins in Brünn and we shall refer to them as 'Transactions' (1866). It is well known that only thirty-four years later the importance of Mendel's work became recognized.

The minds of the historians of science have always been exercised by the almost universal neglect of Mendel's discoveries by his contemporaries. Most authors agree with Iltis (1924), Mendel's most distinguished biographer, who thought that the scientific world at large was no more prepared or capable of accepting Mendel's ideas than the members of the Natural History Society of Brünn, and that Mendel's application of algebra to biology must have reminded his few readers of the Pythagorean numerical mysticisms. According to Nordenskiöld (1927), Mendel's approach was utterly at variance with the prevailing biological concepts and 'it would have been miraculous if it had been supported by a generation brought up on Haeckel's Natural History and Creation'. De Beer (1964), whilst stressing that Mendel's paper was 'too short' to draw attention to it, sees the chief reason for the neglect in the utter unpreparedness of contemporary biologists for Mendel's inferences. Dunn (1965) said 'Nineteenth-century biologists were not looking for the kind of theory Mendel proposed'. Wilkie (1962) suggested that in 1866 Mendel's elaborate theses must have seemed the work of an eccentric and also stressed the contemporary impotence of separating the problems of heredity from those of the nature and origin of species.

Similar views have been held by Gasking (1959), Singer (1950), Sorsby (1965), and Krumbiegel (1957).

The preoccupation of biologists with Darwin's Origin of Species (1859) undoubtedly played a strong part in what Zirkle (1964) aptly called the 'Great Neglect'. Bateson, who was Mendel's first and most vociferous prophet in the Anglo-Saxon world condemned the 'neglect of experimental study of the problem of Species which supervened on the general acceptance of the Darwinian doctrines ...' $(1909$, p. 333). Olby $(1966$, p. 142) stressed the contemporary belief that the study of constant forms cannot lead to the source of variations, and that Mendel's concept of heredity was

* Dr. Skutil died whilst this paper was being prepared. 


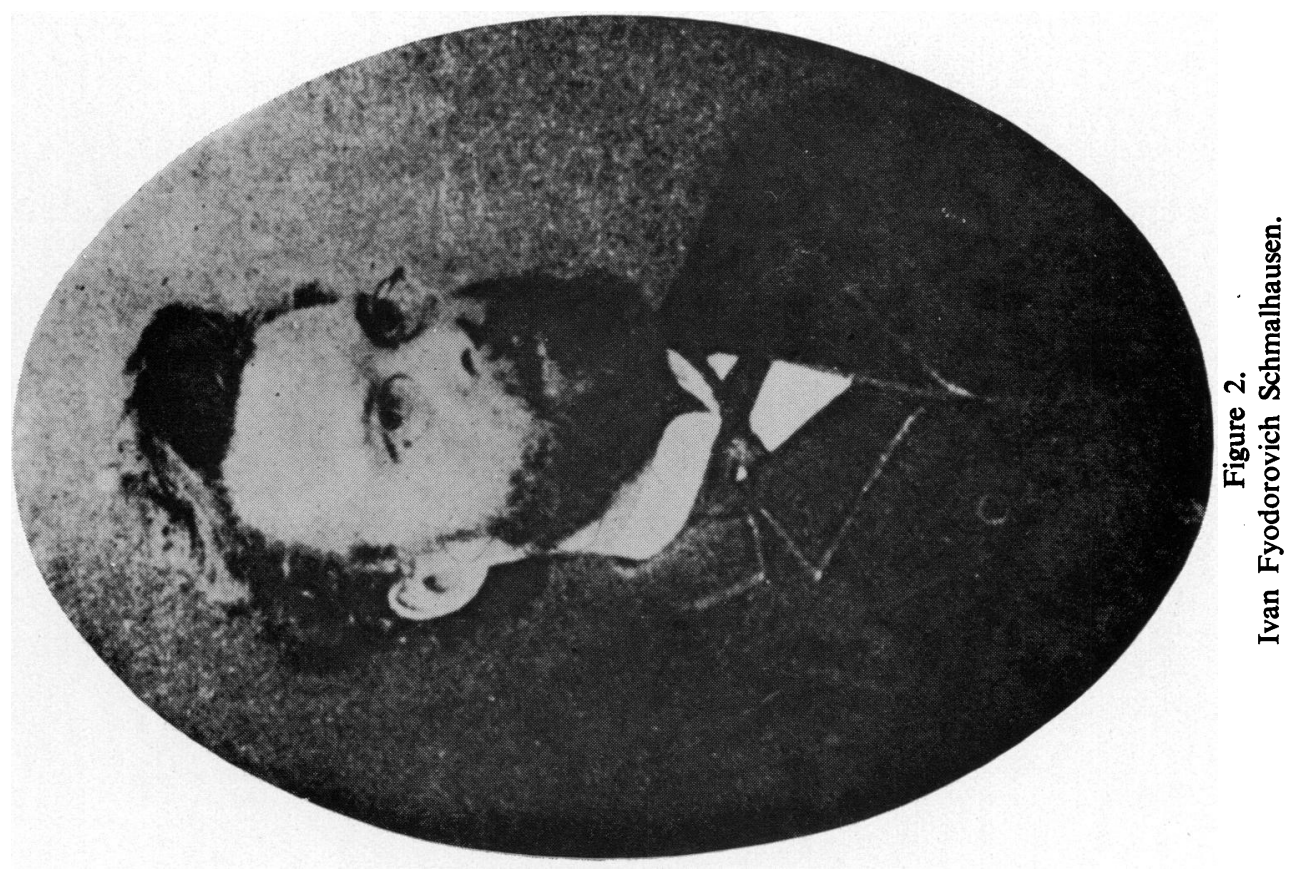

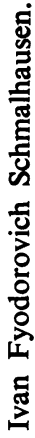

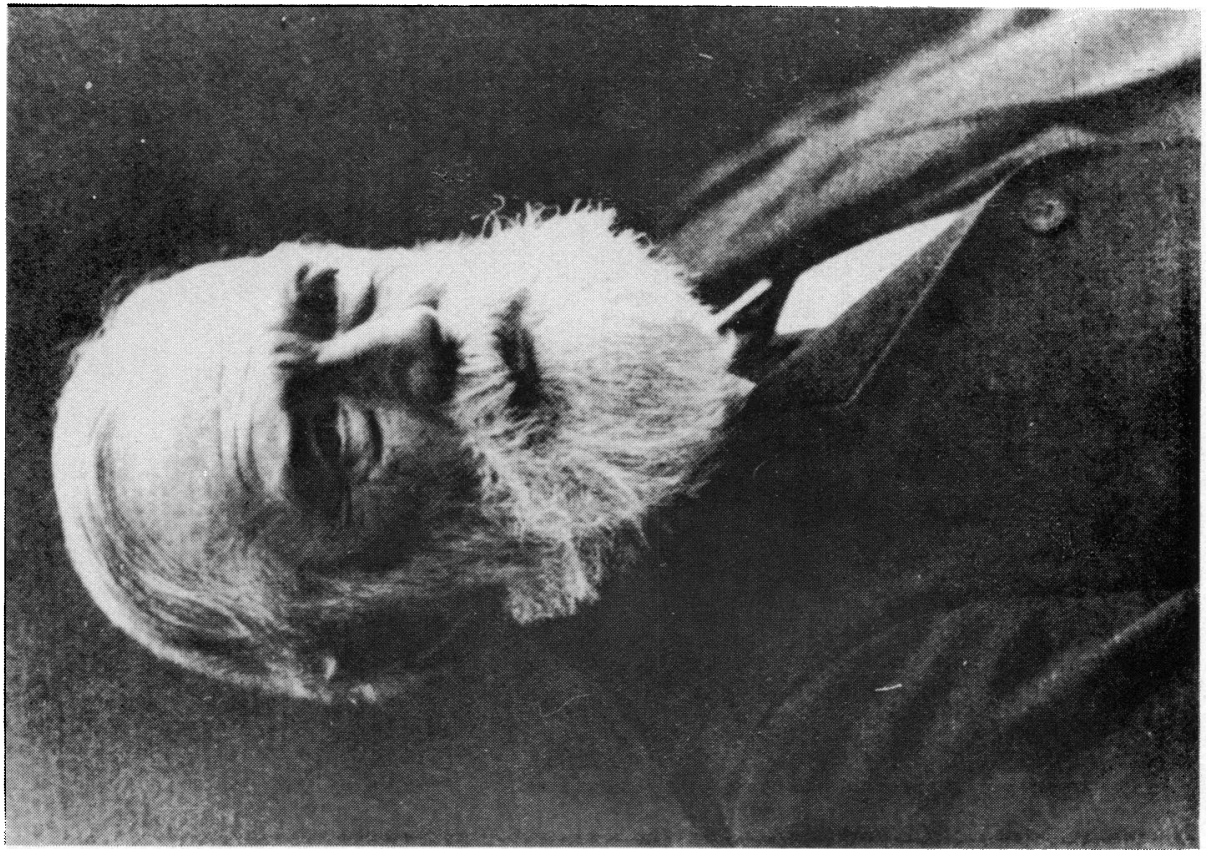

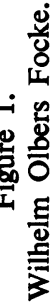




\section{The Great Neglect}

unacceptable to any Darwinian. These undoubtedly valid explanations highlight one of the great ironies in the history of science. It is well known that Darwin's scientific adversaries fastened on his acceptance of 'blending heredity' and on the 'swamping effect', by which they meant that the few mutant characters arising within a wild type population when bred back will be swamped by the large reservoir of normal types. This process would sooner or later deprive natural selection of anything to select from. H. C. Fleeming Jenkin (1833-1885), the Scottish engineer who gave Darwin 'so much trouble' (F. Darwin, 1903), expressed this argument somewhat crudely. 'A highly favoured white cannot blanch a nation of negroes' (1867). Francis Bowen (1811-1890), professor of philosophy at Harvard who according to Vorzimmer (1963) was pushed into the Darwinian battle by Louis Aggasiz (1807-1873), wrote: in nature they will interbreed ... and will thereby kill out instead of multiplying their variations' (1860). In France, Pouchet (1800-1872) thought that through crossbreeding new variations will 'quickly disappear at the tenth if not at the first generation ...' (1864). Darwin was never able to meet these objections. It is a mute point whether a knowledge of Mendel's hypotheses of uncontaminated particulate segregation would have resolved his difficulties.

On the other hand Bateson's suggestion $(1909$, p. 329) 'that Mendel did not find himself in full agreement with Darwin's views, and embarked on his experiments with peas' has been shown to be a chronological non-sequitur by Fisher (1936), and by de Beer (1964). Mendel started his Pisum experiments before publication of Darwin's Origin in 1859, and is unlikely to have read it before the publication of the second German edition in 1863. Furthermore Fisher (1936), has convincingly shown that Mendel, far from being motivated by anti-evolutionary sentiments, was inspired by Darwin's work and considered the evolution of organic forms as an axiomatic fact. The allegations by Richter (1941), Matoušková (1959), and Crowther (1952) that Mendel openly and violently opposed Darwin, lack any documentary basis (Křiženecký 1964, Posner and Skutil 1967).

Naturally the publication of Mendel's paper in the journal of a little-known provincial society has been widely held responsible for its neglect. However Iltis (1924) pointed out that the vigorous naturalists of Brünn were disinclined to 'hide their lights under a bushel'. Bateson (1909, p. 334), Fisher (1936), Zirkle (1964) and others commented on the wide distribution of the 'Transactions'. Shortly before his death, Professor Křiženecký, apart from Iltis, Mendel's most distinguished biographer, wrote: 'More publicity which Mendel's paper could have reached soon after publication would be most important' $(1965$, p. 19).

This bequest and Sir Robert Platt's remark (1959): 'It is extremely difficult to get hold of the original work ...' made us set out on the search for the remaining originals of the 'Plant Hybridization'.

\section{THE MANUSCRIPT AND AUTHOR'S COPIES}

Six months after Mendel's death in 1884, his successor in office, Abbot Ramboušek told Mendel's favourite nephew: 'Your dear uncle left a lot of letters and other "Geschreibsel"- -scribblements-and I wonder what to do with them. Perhaps it will be the best to burn the lot' (Schindler, 1928). 


\section{E. Posner and J. Skutil}

The 'Geschreibsel' may well have included Mendel's lost notebooks of his Pisum experiments whose study could perhaps elucidate the still disputed reasons why some of Mendel's segregation rates were too good to be true (Fisher 1936). Miraculously Mendel's manuscript escaped the ensuing wholesale disposal of his worldly possessions and was found twenty-five years later by Iltis. It is sad to report that this priceless document was lost during the very last days of World War II when a mob looted a bank in Brno (Križenecky 1963).

The title page of the manuscript bore the editor's remark ' 40 reprints'. Publication of the 'Transactions' was delayed, presumably as a result of the Austro-Prussian war of 1866. Mendel received his author's copies at Christmas 1866 and on New Year's day of 1867 he sent one of the forty reprints to Anton Kerner, later 'von Marilaun' (1831-1898), who was at that time professor of botany at Innsbruck. Mendel seems to have known of Kerner's important work on transplantation and hybridization of plants which culminated in his book The Natural History of Plants (1895). In a covering letter Mendel alluded to Kerner's 'interest in hybridization under natural conditions'. Later, Kerner stressed the stability of hereditary characters under changing environmental conditions but, as he never cut the pages of the reprint (Stubbe 1965, p. 135), he could not have been strengthened in his beliefs by Mendel's famous paragraph:

... It is freely admitted that cultivation favours the origin of new varieties ... However nothing justifies the assumption that the tendency of forming varieties is so extraordinarily increased that species loses all stability and that their offspring diverge into an endless series of extremely variable forms. (1866, p. 36).

Towards the end of his life Kerner took a cynical view of the laws of heredity: 'the only law of heredity is this: there is no law of heredity' (Richter, 1942). Kerner's reprint is now at the Botanical Institute at Vienna.

The only other man who is known to have received Mendel's reprint in 1867, was Carl Wilhelm Naegeli (1817-1891), professor of botany at Munich. He lost no time in cutting its pages, an act fateful to Mendel and to Naegeli's posthumous scientific reputation.

Mendel had probably heard of Naegeli from his teacher at Vienna, Franz Unger (1800-1870), at that time one of Naegeli's many admirers (Olby, 1966, p. 111). He may have felt that Naegeli's Fragestellung (1865) if not his answers were close to his own:

... the question may reasonably be asked whether the hybrid ever inherits equally from its parents or whether the one or the other has not always the preponderance . . . As a rule the character of father and mother combine and interpenetrate ... In each individual hybrid both influences make themselves felt. Characters are not transmitted unchanged from one parent or the other ... [ [our italics].

Fisher (1965) suggested that these words were intended to discourage Mendel without having to name him, but at that time Naegeli had not received Mendel's paper.

On the other hand Naegeli's patronizing and unhelpful behaviour towards the amateur Mendel is well known. Whether it was due to a considered rejection of Mendel's hypotheses-'your ratios are empirical not rational', as Weinstein (1962) 


\section{The Great Neglect}

believes, or to a complete failure to grasp Mendel's ideas, can be disputed. Like Mendel, Naegeli was a convinced evolutionist although he had rejected Darwin's mechanism of Natural Selection and had introduced an 'Vervollkommungstrieb' (inner driving force) instead. Like Mendel he believed, or at least looked for a material basis of heredity and he was ahead of Mendel by having seen and sketched chromosomes as early as 1842 (Sirks 1952). Last but not least his work clearly shows that he shared with Mendel a flair for mathematics (Naegeli and Cramer, 1858; Wilkie, 1961).

Indisputable is the fact that Naegeli-almost literally-led Mendel up the garden path to the fateful and frustrating experiments with his pet plant Hieracium-the hawkweed. It became known only many years later that the hawkweed reproduces partly by apomixis, and was thus singularly unsuited to confirm Mendel's results with Pisum: 'I cannot resist to say how striking it is that the Hieracium hybrids behave exactly opposite to those of Pisum ...' (Correns, 1905).

In the year of Mendel's death Naegeli published his magnum opus (1884). By then he had become convinced that parents can transmit equally, or at least almost so in heredity. He quotes dominance of short-haired over long-haired cats in the F 1, and the occurrence of both types in the F 2 generation. Carefully he points out that the validity and meaning of these results can be proved only by thousands of matings over ten generations and adds: ' . . I I don't know of any breeding experiments carried out in this way which produced decisive results ...' (1884, pp. 199-202).

On the 800 pages of the book Mendel's 'Plant Hybridizations' are not mentioned.

The 'Naegeli reprint' was later acquired by the cytologist Boveri, and is now at the Max Planck Institute in Tübingen (Křiženecký, 1965, p. 19).

The only other author's copy of Mendel's paper which has been retrieved outside Brünn, has become an important document in the controversial story of the 'rediscovery of Mendel's work' by Hugo de Vries (1848-1935), Carl Correns (1864-1933), and Erich von Tschermak-Seysenegg (1871-1962). That copy does not carry any correction of misprints which is almost certain proof that it was not sent out by the meticulous Mendel himself (Kłiženecký 1965, p. 20). It somehow reached the Dutch biologist Martinus Willem Beijerinck (1851-1931), who is today little known outside his own country-perhaps undeservedly so. Some of his writings at least carry the marks of prophecy: 'Though the culture of microbes compared to that of higher plants and animals is subject to difficulties, it cannot be denied that microbes are an extremely useful material for the investigations of the laws of heredity.' (1900).

Beijerinck seems to have received the reprint before 1889 (Weiling, 1966) but it is not known what he thought of it. In later years he regretted having given up hybridization at Wageningen for work in a yeast and spirit distillery at Delft: ' $\mathrm{Had}$ I stayed at Wageningen ... I should have also discovered the Mendelian laws ....' (Den Dooren de Jong, 1940).

He sent the reprint with a covering note to Hugo de Vries: 'I know that you are studying hybrids so perhaps the enclosed reprint will still interest you.' (Stomps, 1954, Jahn, 1965).

It would be highly interesting to know the exact date when Hugo de Vries received Beijerinck's letter, because the enclosed reprint of Mendel's paper has become the main exhibit in the still continuing controversy with regard to de Vries's claim to 


\section{E. Posner and J. Skutil}

priority and even to his scientific integrity. However the dates given in literature are conflicting. Olby (1966, pp. 127-29) believed that Beijerinck's Dannean present must have reached de Vries at the time of submitting his papers to German and French journals (1900 a \& b), and that he was only able to add a footnote to the German paper which referred to Mendel's priority: 'these two laws have been postulated many years ago by Mendel for the specific case of Pisum. They have been forgotten or misunderstood'. On the other hand Kruytzer (1967) believes that de Vries may have seen the reprint as early as 1889 which would have given him sufficient time to mention Mendel in both his papers. Some chronological oddities in the submission and publication of de Vries's papers confuse the issue, a confusion which de Vries did little to dispel in later years by giving different versions as to when, how and where he first found a reference to Mendel's work (Roberts, 1929, Stomps 1954, Jahn 1965, Olby 1966, pp. 126-27).

One important point strongly suggests that de Vries had known of Mendel's work whilst writing his own contributions: in both papers he used the term 'recessive' which, according to Kruytzer (1965), no other scientist except Mendel had used in that context between 1865 and 1900 .

After 1900 de Vries's attitude towards Mendelism became ambiguous and even hostile. In summarizing contemporary knowledge of fertilization and hybridization he mentioned most workers in that field with the notable exception of Mendel (1903). He also refused to contribute to a fund for the erection of a Mendel statue, unwittingly aligning himself with the parochial councillors of Brün who objected to the placement of the monument in the square where it might obstruct business at the Annual Fair.

The Beijerinck/de Vries reprint is now in the Botanical Institute of Amsterdam.

Two other reprints of Mendel's papers have been found in Brünn, one quite recently (Weiling 1966). They are both in the Moravian Museum.

THE EXCHANGE COPIES OF THE 'TRANSACTIONS', 1866

Prof. Křženecký and Dr. V. Orel the directors of the Gregor Mendel Department of genetics at the Moravian Museum in Brno kindly provided us with a list of the 115 universities, academies and scientific societies in Europe and in the United States with whom the Natural History Society of Brünn had standing exchange arrangements of their publications in 1867. For brevity we show in Appendix I only those institutions which were connected with leading scientists of that time. We grouped the places according to the political geography of 1867 but anticipated the unification of Germany by five years.

An enquiry action gave us the pleasant surprise that not less than forty-one of the original copies of the 'Transactions' still exist in Great Britain and on the European continent. Their present location is shown in Appendix II. This list may be a considerable understatement as a number of our enquiries were not answered. In addition Dorsey (1944) reported that in 1943 twenty-one American libraries listed Volume 4 of the 'Transactions'. Of these only three seem to have been received soon after the publication of Mendel's paper. Dunn $(1965$, p. 19) bought one copy in Germany as late as 1928 and presented it to Columbia University only to find that a sister volume 


\section{The Great Neglect}

had been there since 1897. According to Weinstein (1962) the copy at Harvard University came originally from the library of the German botanist Alexander Braun (1805-1877).

Dr. W. Coleman (1966) kindly told us that William Bateson acquired as many copies of the 'Transactions' as he could find and distributed them amongst his friends. He sent one copy to Carl Correns and seems to have placed one in the John Innes Institution.

We shared our pleasant surprise in finding so many copies of the original 'Transactions' with a number of librarians of small German and Swiss natural history societies who had not been aware of having the valuable volumes in their custody. On the debit side we found that twelve copies were destroyed as the result of air raids on German cities in 1944-45, and that one was stolen in St. Louis.

Appendix I makes it clear that practically all prominent biologists of the midnineteenth century had access to Mendel's paper but our enquiry as to whether any of them had consulted it produced no definite answers.

In Great Britain the 'Transactions' were duly received by the Royal Society, the Linnaean Society and by the Natural History Society of Dublin in 1867 (Librarians 1965), but no records of loans have been kept that far back. It is however virtually certain that neither Darwin nor his followers or adversaries ever took the volumes from the library shelves of these institutions. Bateson $(1909$, p. 334) thought that 'if Mendel's work had come into the hands of Darwin it is not too much to say that the history of the development of evolutionary philosophy would have been very different from that which we have witnessed'. It seems however doubtful whether Darwin who had confessed his ignorance of 'the great principles of mathematics' (F. Darwin, 1929) would have appreciated Mendel's algebra. Furthermore, Darlington (1960, pp. 51-52) pointed out that Darwin had already in 1864 rejected Naudin's hypotheses which, though in some respects similar to those of Mendel lacked their elaborate mathematical expression.

His cousin, Francis Galton (1822-1911), might have done so. His competence as a mathematician and statistician needs no emphasis, and Olby (1966, pp. 70-72) has only recently unearthed one of his letters in which he set out a Mendelian ratio explained in almost Mendelian terms. Galton lived to hear of Mendel's posthumous fame but according to Fisher (1965) never quite realized how much Mendel's research justified his own views. Nevertheless he paid Mendel a very handsome compliment: 'I must pay tribute to the memory of Mendel with whom I feel sentimentally connected owing to me having been born in the same year 1822 . . . Mendel clearly showed that there were such things as alternative atomic characters of equal potency in descent ...' (Galton, 1909).

Eight years after Mendel's death August Weismann (1834-1914) reviewed the whole field of heredity in his classic work Das Keimplasma (1892). In the preface he postulated the: 'necessity for assuming the existence of an organised, living substance, transmitted from one generation to the next, in contrast to the substance which constitutes the mortal body of the individual. Thus originated my papers on the germplasm and its continuity.' (p. XI.)

After confounding the hypothesis of hereditary transmission of acquired characters, 


\section{E. Posner and J. Skutil}

he continued: 'The research of many excellent scientists with regard to fertilization and conjugation-in which I was privileged to have a share-led to a complete revolution in our previous ideas as to the nature of these processes and convinced me that the germ plasm consists of vital units of equal value each of which contains all constituents (Anlagen) of the individual but differ from each other individually ...' (p. XII).

On the following 600 pages Mendel's name does not appear among the many biologists who brought that 'complete revolution' about. The two copies of the 'Transactions' sent to Freiburg had escaped Weismann's notice, as had the reference to Mendel by Focke (see below) whose work he discussed in some detail (1829, pp. 341, 350, 392, 396, 504).

Weismann's 'revolutionaries' at that time were Strassburger (1844-1912), Van Beneden (1845-1910), Flemming (1843-1905), Koelliker (1817-1905), O. Hertwig (1849-1922), Boveri (1862-1915), Roux (1850-1924), Wilson (1856-1939), and others. They were busy, as Muiller wrote in 1943, with 'preparing cytology for Mendelism'. All of them had access to the 'Transactions' but none of them is known to have seen them before 1900. Neither is Rudolf Virchow (1821-1902), who must have received the 'Transactions' as an honorary member of the Natural History Society of Brün.

France had become a main centre of plant hybridization mainly through the work of Louis Leveque Vilmorin (1816-1860), but strangely enough no copy of the 'Transactions' was sent to Paris. When C. W. Eichling went on a fact-finding tour of Europe for a seed firm in Nancy, a well-known seedgrower in Erfurt, Ernest Benary, recommended a visit to Abbot Mendel, which suggests that Benary had seen the 'Transactions' which were sent to Erfurt. Eichling got his audience with the Abbot and an excellent luncheon, but Mendel refused to enlighten him on the subject of peas (Eichling 1942). Charles Naudin (1815-1899) of Paris, who had won the 'prix des sciences physiques' for his essays on plant hybridization $(1856,1863,1865)$, has sometimes been thought to have been a forerunner of Mendel. His disinclination to evaluate his results mathematically and his ideas of the 'variations disordones' in the F 2 generation of hybrids-an idea diametrically opposed to Mendel's-shows the vast difference in their approach. Naudin is unlikely to have seen the 'Transactions' in Cherbourg or Strassbourg.

Finally in Mendel's homeland, J. E. Purkyne (1787-1869), who was one of the foremost European biologists of the time and also an honorary member of the Natural History Society of Brünn-failed to notice Mendel's paper, and for that matter the rows of peas in the garden of the St. Thomas monastery of Brinn which he is known to have visited (Saijner, 1965).

Only few men who are today mostly forgotten noticed Mendel's paper before 1900 and only one came near to grasping its implications. The 'Transactions' sent to the 'Oberhessische Gesellschaft für Natur und Heilkunde' in Giessen were duly received, and later transferred to the university library. They were destroyed in an air raid in 1944. From them H. K. H. Hoffmann (1819-1891) culled the first reference to Mendel's work. In a critique of Darwin's hypotheses he allotted Mendel eighteen lines, sixteen of which dealt with Mendel's experimental methods and two with his results: 'Hybrids show the tendency to revert to their original species in subsequent generations' 


\section{The Great Neglect}

(1869). This short summary was unlikely to draw the attention of Hoffmann's readers to Mendel's original work. Punnett (1925) thought 'that Darwin must have seen that', but Olby (1966, p. 195), whilst confirming that Darwin had annotated Hoffmann's book, found the relevant page unmarked.

In 1881 a physician of Bremen, Wilhelm Olbers Focke (1834-1922), produced the result of many years' diligent labour-the Pflanzenmischlinge (plant hybrids). Focke (Fig. 1) was an expert on roses and blackberries, but on his own admission he was not an original experimenter. He tried to 'marshall all the known facts about hybridization'. In a letter to Ernst Haeckel (1834-1919), quoted by Jahn (1965), he expressed his hope 'to disperse many stupid and ridiculous superstitions which humanity harbours in the field of hybridization'. He considered Mendel's work 'most instructive, and in other places he listed him in one breath with famous botanists such as Gaertner' Naudin, Wichura and Koelreuter. About his Pisum results he had only this to say: -... Mendel's numerous hybridization tests gave results similar to those of Knight, but Mendel believed to have found constant numerical ratios between the hybrid types'.

The orator who pronounced on the occasion of Focke's eightieth birthday: 'Your Plant Hybridization has been for decades the only reliable source and base line for experiments in that field ...' (Naturw. Verein Bremen, 1914), quite understandably overstated his case, but Focke's laconic reference to Mendel's Pisum experiments aroused the curiosity of two of Mendel's re-discoverers-Correns and Tschermak (Jahn, 1965).

Charles Darwin also possessed a copy of Focke's book (Olby, 1966, p. 195), and lent it to J. G. Romanes (1848-1894) who had been commissioned to edit the chapter on hybridization for the Encyclopaedia Britannica of 1881 (Edwardson 1962). Olby (1967) believed that Romanes distilled from Focke's book a list of those 'who within still more recent years have contributed to the literature of hybridism'. He mentioned Mendel without giving further details of his work.

The Director of the College of Agriculture at Cornell University, L. H. Bailey (1858-1954), had also seen the references to Mendel in Focke's book and mentioned him shortly in a paper published in 1892, a reprint of which he sent to Hugo de Vries. Bailey later admitted to Roberts $(1929$, loc. cit. p. 323) that he did not see Mendel's paper until 1900.

One of the two copies of the 'Transactions' which were sent to St. Petersburg must have been very carefully read by the young botanist Ivan Fyodorovich Schmalhausen (Fig. 2). After completing his magisterial thesis About Plant Hybrids: Observations on the Petersburg Flora (1874), he added a footnote which is the most perspicacious summary of Mendel's hypotheses before 1900. Schmalhausen (1849-1894) said: 'I got to know of Mendel's paper only after my thesis had gone to press. However I must refer to it because the author's methods and his mathematical presentation deserve the closest attention and should be further pursued. Mendel set himself the task to count the different types of hybrids with mathematical accuracy and to establish the ratios of the different individual types... . [our italics].

One should notice that Schmalhausen referred to Mendel's supremely important ratios whereas Hoffmann and Focke did not even mention that Mendel had counted 


\section{E. Posner and J. Skutil}

his peas. Also Darwin (1868) had not noticed that his snapdragon-hybrids had segregated in a ratio very close to $3: 1$.

Schmalhausen then described fairly but not quite accurately, Mendel's segregation and recombination hypotheses, and regretted that the German botanist Koernicke (1872) had not used Mendel's methods and 'was thus unable to produce any numerical data'.

Filipitschenko (1925) and Gaisinovich (1935) first drew attention to Schmalhausen's brilliant understanding of Mendel's mathematical approach, and one of the martyrs of Mendelism, N. I. Vavilov, quoted him in the introduction to the Russian translation of Mendel's paper in 1935. Full accounts of Schmalhausen's thesis have recently been given by Gaisinovich (1965), Weiling (1966), and Orel (1966).

Alas, Schmalhausen, having exhorted his fellow botanists to 'pursue the matter further', did nothing of the kind himself. When he elaborated his thesis in a German journal (1875) he omitted the footnote referring to Mendel (Weiling 1966). His interests shifted to Paleobotany and he became Keeper of the Botanical Gardens at Petersburg and Kiev (Lipskii, 1913-1915). A few flowering shrubs and plants carry his name but he never knew how close he came to be the first rediscoverer of the fundamental laws of genetics.

Mendel himself did little to make his work known. He never attempted nor was he encouraged to publish his papers in widely known scientific journals. In his obituary notice which he had drafted himself, he said nothing of his scientific pursuits (Fig. 3). The secretary of the Natural History Society of Brünn summarized in his commemorative address his friend's botanical exploits in one sentence: 'He evaluated his prolonged and painstaking experiments in a peculiar manner' (Orel, 1965, our italics).

In spring of 1900 de Vries, Correns and Tschermak presented the news of their independent discovery of Mendel's segregation laws (de Vries, 1900 a \& b; Correns, 1900; Tschermak, 1900 a \& b). Correns had calculated segregation laws for fun ('allotria') and had realized their significance after a disturbed night (1922). Tschermak had found the reference to Mendel in Focke's book and mobilized his Viennese friends to have his contribution published in a small agricultural journal (1960).

W. Bateson (1861-1926) first saw Mendel's name in de Vries's paper for the German Botanical Society $(1900 \mathrm{~b})$ and immediately hunted out the 'Transactions', presumably from the Library of the Linnaean Society. According to his wife (B. Bateson, 1928) he read them on his way from Cambridge to London 8 May 1900, and a few hours later he told the members of the Royal Horticultural Society: 'Mendel's principles which he was able to deduce from his experiments will play a conspicuous part in all future discussions of evolutionary problems . . ' (1901).

In 1902 Bateson and Cuenot (1866-1951) confirmed the validity of Mendel's laws in animals (Bateson, 1902a; Cuenot, 1902). During the same year it was still possible to state: 'Mendel's results do not justify any general statements concerning inheritance in crossbred peas . . .' (Weldon, 1902). But also in 1902, A. Garrod (1857-1936) wrote about alkaptonuria in the Lancet: 'It has recently been pointed out by Bateson that the law of heredity discovered by Mendel offers a reasonable account of such phenomena ... There seems little room for doubt ... that the peculiarity of the gametes of both parents is necessary for its production.' 


\section{The Great Neglect}

Garrod referred to Bateson's Mendel's Principles of Heredity (1902b) which bears the subtitle: 'A Defense'. When the book was republished in 1909, 'A Defense' had been dropped from the title page. The Great Neglect was over and the inspired guess of the unknown writer in 1884: 'Epoch making were Mendel's experiments in plant hybridization', had finally become universally accepted.

\section{ACKNOWLEDGEMENTS}

We cannot mention individually the numerous people who helped us with this inquiry, but our thanks are due to all of them. Dr. Kuhbier of Bremen, Miss Shipton of the John Innes Institution at Bayfordbury, Miss Bonfield of the Royal Irish Academy, Dr. J. Blake of the National Library of Medicine in Washington, and Mr. Betts of Columbia University were particularly kind to us. We are grateful to Dr. I. B. K. McGregor and Dr. Olby for valuable suggestions and criticisms. Mrs. M. Hampton patiently and efficiently dealt with a vast amount of correspondence. Mendel's obituary notice is shown by permission of the Director of the Mendel Museum in Brno.

\section{APPENDIX I \\ Universities, Academies and major societies at which Mendel's paper was available before 1900 .}

AUSTRIA-HUNGARY:

Graz

Innsbruck

Klagenfurt

Pesth

Prague

Vienna

GERMANY

Berlin

Bonn

Dresden

Erfurt

Erlangen

Frankfurt a/M.

Freiburg/Breisgau

Giessen

Göttingen

Hamburg

Heidelberg

Kiel

Königsberg

Munich

Stuttgart

Würzburg
Naturwissenschaftlicher Verein Steiermark

Ferdinandeum.

Naturhistorisches Landesmuseum

Kgl. ungarische Gesellschaft f. Naturwissenschaften

Kgl. boehmische Gesellschaft der Naturwissenschaften

Kais. Akademie der Wissenschaften

Kais. -Kgl. zool. -bot. Gesellschaft

Kgl. Akademie der Wissenschaften

Physikalische Gesellschaft

Naturwissenschaftlicher Verein der Rheinlande

Kais. Leopoldinische Carolinische Akademie

Naturwissenschaftlicher Verein 'Isis'

Kgl. Akademie der Wissenschaften

Kgl. Universität

Physikalische Gesellschaft

Zoologische Gesellschaft

Grossherzogliche Universität

Naturforschende Gesellschaft

Oberhessiche Gesellschaft für Natur und Heilkunde

Kgl. Universität

Naturwissenschaftlicher Verein

Naturhistorisch-Medizinischer Verein

Verein zur Verbreitung naturwissenschaftlicher Kenntnisse

Königliche Universität

Bayrische Königliche Akademie der Wissenschaften

Verein für Vaterländische Naturkunde

Physikalische-Medizinische Gesellschaft 


\section{E. Posner and J. Skutil}

GRBAT BRITAIN AND IRELAND:

Dublin

London

Natural History Society

Royal Society

Linnaean Society

Greenwich Royal Observatory

FRANCE AND LOW COUNTRIES:

1. Amsterdam

2. Brussels

3. Cherbourg

4. Strassbourg

Koninklijke Nederlandse Akademie Van Wettenschappen

Académie Royale des Sciences Naturelles

Société Impériale des Sciences Naturelles

Société des Sciences Naturelles

RUssta:

Moscow

St. Petersburg

Société Impériale des Naturalistes

Imperial Academy of Sciences

Société Impériale Geographique de la Roussie

SCANDINAVIA:

Helsingfors

Stockholm

Societas Scienciarum Finnica

Uppsala

Royal Swedish Academy of Sciences

Societeten. Kungl. Vetenskaps

ITALY:

Venice

Instituto di Scienze

SWITZERLAND:

Basel Naturforschende Gessellschaft

Bern

Naturforschende Gesellschaft

Zürich

Universität

Schweizerische Naturforschende Gessellschaft

UNITED STATES OF AMERICA:

Academy of Natural Sciences of Philadelphia

American Academy of Arts and Sciences, Boston

Boston Society of Natural History

Columbia University Library

Harvard University Library

Library of Congress and Smithsonian Institution

New York Public Library

U.S. Army Medical Library, Washington, D.C.

U.S. Department of Agriculture, Library

\section{APPENDIX II}

Institutions known to possess the original Transactions of the Natural History Society of Brünn, (Vol. IV.) in 1967

AUSTRIA:

1. Graz

2. Innsbruck

3. Klagenfurt

4. Linz

5. Vienna
Steiermaerkische Landesbibliothek

Tiroler Landesmuseum

Landesmuseum für Kärnten

Landesmuseum

Geologische Bundesanstalt

Österreichische Akademie der Wissenschaften 


\section{The Great Neglect}

FRANCE:

6. Strassbourg

HOLLAND:

7. Groningen

GERMANY:

8. Berlin

9. Berlin

10. Bonn

11. Elberfeld-Wuppertal

12. Erfurt

13. Freiburg/Breisgau

14. Freiburg/Breisgau

15. Göttingen

16. Hannover

17. Heidelberg

18. Karlsruhe

19. Marburg (Lahn)

20. Passau

21. Regensburg

22. Wiesbaden

EASTERN EUROPE:

23. Brno (Czechoslovakia)

24. Prague (Czechoslovakia)

25. Zagreb (Jugoslavia)

26. Gdansk (Poland)

27. Wroclaw (Poland)

28. Budapest (Hungary)

29. Bibiu (Roumania)

EIRE:

30. Dublin

UNITED KINGDOM:

31. London

32. London

33. Bayfordbury, Herts.

SCANDINAVIA:

34. Helsinki

35. Stockholm

36. Uppsala

SWITZERLAND

37. Basel

38. Bern

39. Graubuenden

40. St. Gallen

41. Zürich
Bibliothèque Nationale et Universitaire

University Library

Deutsche Akademie der Wissenschaften

Institut für Vererbungsforschung, Technische Universität

Naturhistorischer Verein der Rheinlande und Westfalens

Naturwissenschaftliches Museum

Wissenschaftliche Bibliothek Erfurt

Universitätsbibliothek

Geologisches Landesamt

Akademie der Wissenschaften

Deutsche Geologische Gesellschaft

Universitätsbibliothek

Technische Hochschule

Universitätsbibliothek

Naturwissenschaftlicher Verein

Naturwissenschaftlicher Verein

Nassauischer Verein für Naturkunde

Moravské Museum

Čskoslovenská Akademie Věd

Central Agricultural Library

Biblioteka Polskiej Akademii Nauk

Biblioteka Uniwersytecka

Muzeum Konytvara

Muzeul Bruckenthal

Royal Irish Academy

The Royal Society

The Linnaean Society

John Imes Institute

Library of the Scientific Societies

Royal Swedish Academy of Science

Royal Society of Sciences

Universitätsbücherei

Universitätsbibliothek

Kantonsbibliothek

Stadtbibliothek

Zentralbibliothek

\section{REFERENCES}

Anonymous, Mbr. Obst., Wein u. Gartenbau-Sektion der K.K. Mäerisch-Schlesischen Ges. z. Beförderung des Ackerbaus, der Natur u. Landeskunde, 1844, 1, 3.

BAIIEY, L. H., Crossbreeding and Hybridization, Rural Library Series, 1-44, New York, 1892. 


\section{E. Posner and J. Skutil}

Bateson, B., William Bateson, F.R.S., Naturalist, Cambridge University Press, 1928.

Batzson, W., 'Problem of heredity as a subject for horticultural investigations', Jl. $R$. hort. Soc., 1901, 25, 54-61.

Idem., Poultry, Reports to the Evolution Committee of the Royal Society. London, 1902a, 1, 87-124.

Idem., Mendel's Principles of Heredity. A Defense, London, $1902 \mathrm{~b}$.

Idem., Mendel's Principles of Heredity, Cambridge University Press, 1909.

BeER, SiR Gavin De, 'Mendel, Darwin and Fisher', Notes Rec. R. Soc. Lond., 1964, 19, II, 192-226.

BeiJerInck, M. W., 'On different forms of hereditary variations of microbes', Proc. Sci. $K$. Akad. Wet. Amst., 1900, 3, 325-65.

Bowen, F., 'Review', Am. J. Sci. Arts, 1860, p. 500 (quoted from Vorzimmer 1963).

Coleman, W., personal communication, 1966.

Correns, C., 'Mendels Regeln über das Verhalten der Nachkommenschaft der Rassenbastarde', Ber. dt. bot. Ges., 1900, 18, 158-68.

Idem., Gregor Mendels Briefe an Carl Naegeli, 1866-1873, Leipzig, Teubner, 1905.

Idem., 'Etwas über Mendels Leben und Wirken', Naturwissenschaften, 1922, 10, 623-31.

Crowther, J. C., British Scientists of the Twentieth Century, London, Routledge \& Kegan Paul, 1952.

Cunnot, L., 'La loi de Mendel et l'hérédité de la pigmentation chez les souris', Archs. Zool. exp. gén., 1902, 3, 27-30.

Darlington, C. D., Darwin's Place in History, Oxford, Blackwell, 1960.

Darwin, Charles, Origin of Species, London, Murray, 1859.

Idem., Entstehung der Arten im Tier und Pflanzenreich durch natürliche Züchtung, Stuttgart, Schmeizerbart, 1863.

Idem., The Variations of Animals and Plants under Domestication, London, Murray, 1868.

DARwIN, F., More Letters of Charles Darwin, New York, 1903, vol. 2, p. 379.

DARWIN, F. (ed.), Autobiography of Charles Darwin, London, Watts, 1929, p. 21.

Den Dooren de Jong, L. E., in Beijerinck, His Life and Work, The Hague, 1940.

DoRSEY, M. J., 'Appearance of Mendel's paper in American libraries', Science, 1944, 99, 199-200.

DunN, L. C., Short History of Genetics, New York, McGraw Hill, 1965, p. 19.

EDwardson, J. R., 'Another reference to Mendel before 1900', J. Hered., 1962, 53, 152.

EICHLING, C. W., 'I talked with Mendel', J. Hered., 1942, 33, 243.

Encyclopaedia Brittanica, 9th ed., vol. 12, pp. 422-26, Chicago, Werner, 1881.

Filipitschenko, J. A., Galton i Mendel, Moscow, Gosizdat, 1925.

FisHeR, R. A., 'Has Mendel's work been rediscovered?', Ann. Sci., 1936, 1, 115.

Idem., in Experiments in Plant Hybridization, ed. J. H. Bennett, London, Oliver \& Boyd, 1965 , p. 83.

Focke, W. O., Die Pflanzenmischlinge, Berlin, Bornträger, 1881.

GAISINOVICH, A. E., Isbrannye raboty o rastitelnych gibridach, Moscow and Leningrad, 1935.

Idem., 'The first account of Mendel's work in Russia', Bull. Soc. Nat. Mosc., 1965, 70, 22-24 ('Biologie').

Galton, F., Memories of my Life, London, Methuen, 1909, p. 97.

GARROD, A. E., 'The incidence of alkaptonuria. A study in chemical individuality', Lancet, 1902, ii, 1616-20.

Gasking, E. B., 'Why was Mendel's work ignored?', J. Hist. Ideas, 1959, 20, 60-84.

HoffmanN, H. K. H., Untersuchungen zur Bestimmung des Wertes von Spezies und Varietät.

Beitrag zur Kritik der Darwinischen Hypothese, Giessen, Ricker, 1869, p. 136.

ILtis, H., Mendel, Leben, Werk und Wirken, Berlin, Springer, 1924.

JAHN, I., 'Focke und Beijerinck', Biol. Rdsch., 1965, 3, 12-25.

JeNKIN, H. C. F., 'Origin of species', North Brit. Rev., 1867, 46, 277-318.

Kerner, Marilaun Von, The Natural History of Plants. Their Forms, Growth Reproduction and Distribution, trans. F. W. Oliver, London, 1895, vol. 2, p. 514. 


\section{The Great Neglect}

KOERniCKe, F., 'Vorlaüfige Mitteilungen über den Mais', Verh. Naturw.Ver. preuss. Rheinlande u. Westphalens, 1872, 29, 64.

Ǩ̌ıžENECKÝ, J., Naturw. Rdsch. Braunschw., 1963, 16, 477.

Idem., Anthropologie, Prague, 1964, $2,75$.

Idem., in Fundamenta Genetica, Brno, Moravian Museum, Czechoslovak Academy of Sciences, 1965, p. 19.

KRUYTZER, E. M., 'Honderd Jaar Mendel', Naturhist. Landblaad., 1965, 54, 19-29.

Idem., personal communication, 1967.

KRUMBIEGel, I., Mendel und das Schicksal seiner Entdeckung, Stuttgart, Wissenschaftliche Verlagsgesellschaft, 1957, pp. 105-25.

Librarians of Royal Society, London, Linnaean Society, London, and Royal Irish Academy, Dublin, personal communications, 1965.

LiPSkII, V. I., St. Petersburg Botanical Gardens after 200 Years, 1913-15, pt. 3, pp. 474-79. MatouškovÁ, B., Folia biol., Praha, 1959, 5, 169.

MENDEL, G., 'Versuche über Pflanzenhybriden', Verh. naturf. Ver. Brünn, 1866, 4, 3-47.

Idem., Opyty nad rastitelnymi gibridami, with foreword by N. I. Vavilov, Moscow and Leningrad, Ogisselchorgis, 1935.

MülleR, H. J., 'Wilson, an appreciation', Am. Nat., 1943, 77, 5-37. (Quoted from Dunn, 1965, p. 53).

NAudin, C., 'Observations constantant de le retour simultane de la descendance d'une plante hybride aux types paternels et maternels', C. r. hebd. Séanc. Acad. Sci., Paris, $1856,42,628$.

Idem., 'Nouvelles recherches sur l'hybridité dans les vegetaux', Annls Sci. nat. bot., 1863, $4,19$.

Idem., 'Nouvelles recherches sur l'hybridité dans les vegetaux', Archs. Mus. natn. Hist. nat., Paris, 1865, 1, 25-176.

Verh. naturf. Ver. Bremen, 1914, 23, 1.

NAegel, C., 'Bastardbildung im Pflanzenreiche', Sber. bayer. Akad. Wiss. bot., 1865, 2, 187-235.

Idem., Mechanisch-Physiologische Theorieder Abstammungslehre, München and Leipzig, 1884.

NAEgel, C., and Cramer, C., Pflanzenphysiologische Untersuchungen, vol. 2: 'Die Staerkekörner', Zürich, 1858.

NoRDENSKiöLD, E., The History of Biology, New York, Tudor, 1927, pp. 591-92.

OlBY, R. C., Origins of Mendelism, London, Constable, 1966.

Idem., personal communication, 1967.

Orel, V., Památka na Gregora Mendela, Brno, Blok, 1965, p. 199.

Idem., Die Publizität der Klassischen Arbeit Mendel's vor der Wiederentdeckung im Jahre 1900, Brno, Folia Mendeliana, 1966.

Platt, R., 'Mendel, Darwin and Galton', Med. Hist., 1959, 3, 87-99.

Posner, E., and Skutil, J., 'Mendel and Darwin', Midl. med. Rev., 1967, $2,112$.

Pouchet, G., Plurality of the Human Race, 2nd ed., London, 1864, p. 142.

PunNetT, R. C., 'An early reference to Mendel's work', Nature, Lond., 1925, 116, 606.

Richter, O., '75 Jahre seit Mendel's Stellungsnahme zu Darwins Werken auf Grund seiner Entdeckungen', Verh. naturf. Ver. Brünn, 1941, 72, 110.

Idem., 'Mendel wie er wirklich war', Verh. naturf. Ver. Brünn, 1942, 74, 1-262.

Roberts, H. F., Plant Hybridization before Mendel, Princeton, 1929, p. 323.

SAJNER, J., in Gregor Mendel, Brno, Blok, 1965, p. 141.

SCHINDLER, A., Letter to A. Matoušek, 1928. Quoted from Křiženecký, J., Gregor Mendel, Leipzig, Barth, 1965, p. 104.

SChMAlHAUSEN, I., $O$ rastitelnych pomesjach nabludenja iz petersburkoj flory, university dissertation, 1874.

Idem., 'Aufzälung der im Gouvernement von St. Petersburg vorkommenden Bastard und Zwischenformen', Bot. Ztg., 1875, 33, 537-40, 553-60, 569-78.

Singer, Charles, A History of Biology, London, Lewis, 1950, p. 559. 


\section{E. Posner and J. Skutil}

SIRKs, M. J., 'The earliest illustrations of chromosomes', Genetica, 1952, 26, 65-67.

SORSBY, ARNOLD, 'Gregor Mendel', Brit. med. J., 1965, i, 333.

Stomps, T. J., 'On the rediscovery of Mendel's work by H. de Vries', J. Hered., 1954, 45, 293-94.

STUBвв, H., Kurze Geschichte der Genetik bis zur Wiederentdeckung der Vererbungsregeln Mendels, Jena, Fischer, 1963.

Tschermak-SeysenegG, E., 'Uber Kreuzung von Pisum Sativum', Z. landw. VersWes. Öst., $1900 \mathrm{a}, 3,465-555$.

Idem., 'Uber Künstliche Kreuzung bei Pisum Sativum', Ber. dt. bot. Ges., 1900b, 18, 232-39.

Idem., ‘60 Jahre Mendelismus', Verh. zool. bot. Ges. Wien, 1960, 100, 14-26.

VRIEs, H. DE., 'Sur la loi de disjonction des hybrides', C. r. hebd. Séanc. Acad. Sci., Paris, 1900a, 130, 845-47.

Idem., 'Das Spaltungsgesetz der Bastarde', Ber. dt. bot. Ges., 1900b, 18, 83-90.

Idem., Befruchtung und Bastardierung, Leipzig, Veit, 1903.

Vorzimmer, P., 'Charles Darwin and blending inheritance', Isis, 54, 371-90.

WeIIING, F., 'Mendels Versuche über Pflanzenhybriden und ihre Würdigung in der Zeit bis zur Wiederentdeckung', Züchter, 1966, 36, 273-82.

Wennstein, A., 'The reception of Mendel's paper by his contemporaries', Proc. 10th Congr. Hist. Sci., 1962, vol. 2, pp. 997-1001.

Weismann, A., Das Keimplasma, Jena, Fischer, 1892.

WELDON, W. F. R., 'On the ambiguity of Mendel's categories', Biometrika, 1902, 2, 44-55.

WilkIE, J. S., 'Naegeli and the fine structure of living matter', Nature, Lond., 1961, 190, $1145-50$.

Idem., 'Some reasons for the rediscovery and appreciation of Mendel's work in the first years of the present century', Brit. J. Hist. Sci., 1962, 1, 5-17.

ZIRKLE, C., 'Some oddities in the delayed discovery of Mendelism', J. Hered., 1964, 55, 65-72.
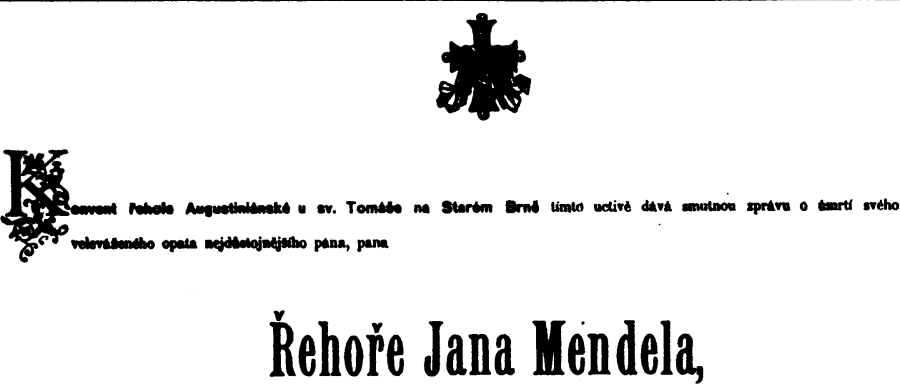

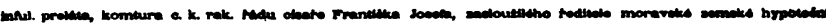

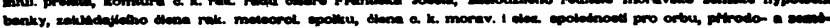

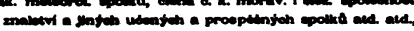

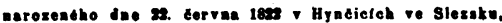

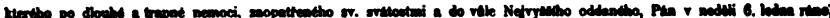

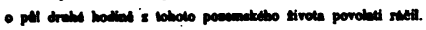

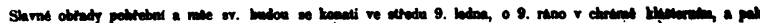

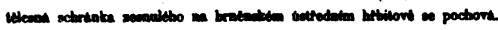

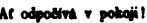

V BRNE, 6. Wom 1824

Figure 3.

Gregor Mendel's self-composed obituary notice. 